\title{
Extreme Wave Analysis by Integrating Model and Wave Buoy Data
}

\author{
Fabio Dentale ${ }^{1,2}$, Pierluigi Furcolo ${ }^{2}$ (D), Eugenio Pugliese Carratelli ${ }^{1,2}$, Ferdinando Reale ${ }^{2, *(D),}$ \\ Pasquale Contestabile ${ }^{1,3}$ and Giuseppe Roberto Tomasicchio ${ }^{4}$ \\ 1 Inter-University National Consortium for Marine Sciences (CoNISMa), 00196 Roma, Italy; \\ fdentale@unisa.it (F.D.); epc@unisa.it (E.P.C.) \\ 2 Civil Engineering Department, University of Salerno, 84084 Fisciano, Italy; p.furcolo@unisa.it \\ 3 Department of Engineering, University of Campania "Luigi Vanvitelli", 81100 Caserta, Italy; \\ pasquale.contestabile@unicampania.it \\ 4 Department of Innovation Engineering, Ecotekne Centre, University of Salento, 73100 Lecce, Italy; \\ giuseppe.tomasicchio@unisalento.it \\ * Correspondence: freale@unisa.it; Tel.: +39-089-964-112
}

Received: 12 February 2018; Accepted: 21 March 2018; Published: 24 March 2018

\begin{abstract}
Estimating the extreme values of significant wave height $\left(\mathrm{H}_{\mathrm{S}}\right)$, generally described by the $H_{S}$ return period $T_{R}$ function $H_{S}\left(T_{R}\right)$ and by its confidence intervals, is a necessity in many branches of coastal science and engineering. The availability of indirect wave data generated by global and regional wind and wave model chains have brought radical changes to the estimation procedures of such probability distribution-weather and wave modeling systems are routinely run all over the world, and $\mathrm{H}_{\mathrm{S}}$ time series for each grid point are produced and published after assimilation (analysis) of the ground truth. However, while the sources of such indirect data are numerous, and generally of good quality, many aspects of their procedures are hidden to the users, who cannot evaluate the reliability and the limits of the $\mathrm{H}_{S}\left(\mathrm{~T}_{R}\right)$ deriving from such data. In order to provide a simple engineering tool to evaluate the probability of extreme sea-states as well as the quality of such estimates, we propose here a procedure based on integrating $\mathrm{H}_{\mathrm{S}}$ time series generated by model chains with those recorded by wave buoys in the same area.
\end{abstract}

Keywords: wave extreme events; Mediterranean Sea; North Atlantic Spanish coasts; Gulf of Mexico; wave modeling; small scale storm variations

\section{Introduction}

The analysis of extremes arises in many branches of science and engineering. Hurricane winds for suspension bridge design and storm surge heights for coastal and offshore works are well-known examples in civil engineering. Extreme value analysis (EVA) is a branch of statistics dealing with the extreme deviations from the median of probability distributions. Knowledge of the value of an extreme event for a given return period $T_{R}$ is the result of the EVA.

In particular, in ocean and coastal engineering, extreme events are described in terms of the function $\mathrm{H}_{S}\left(\mathrm{~T}_{\mathrm{R}}\right)$, which links the significant wave height (in the following: $\mathrm{SWH}$, or $\mathrm{H}_{S}$ ) of a sea state with different return periods $\mathrm{T}_{\mathrm{R}}[1,2]$.

The traditional—and probably also the best-sources of data for such analyses are the historical in-situ (in the following: "direct" or "experimental") wave measurements provided by wave buoy recorders. Buoys measure the motion of the sea surface, and modern buoys also measure slope and lateral motion [3]. Properly analysed [4,5], these data allow an estimate of sea wave properties in terms 
of wave spectrum or, more simply, in terms of the main sea state parameters such as significant wave height $\mathrm{H}_{\mathrm{S}}$, mean and peak period $\mathrm{T}_{\mathrm{m}}, \mathrm{T}_{\mathrm{p}}$ and mean direction $\theta_{\mathrm{m}}$.

However, the number of wave buoys is necessarily limited. For example, the entire Italian Data Buoy Network (in the following Rete Ondametrica Nazionale, RON), operational from 1989 until 2014, consisted of only 15 stations positioned along the more than $7000 \mathrm{~km}$ of Italian coasts [6,7].

As a consequence, it has become a common practice $[8,9]$ to use data (in the following indicated as "indirect data" or "model data") originated from global or regional wave models, which are in turn driven by meteorological wind models. Global and regional wave data are readily available and this favours their extensive use by ocean engineers and researchers. The wave part of the model chain implicitly takes into account the geographical and morphological aspects of the wave formation and propagation, such as the water depth (when applicable) and the variability of fetch, while the meteorological part includes all the information related both to large scale air circulation as well as to "regional" (in a meteorological sense) orography.

However, substantial differences can be found when performing an EVA that considers directly observed and model wave data [10-14]. This difference is primarily due to the obvious fact that direct data, even though affected by errors-like any experiment-are still a more reliable estimate of the true values, compared to a model chain that, despite all the efforts and the care taken, is the result of enormously complicated calculations. The numerical diffusion [13] present in all the models tends to smoothen the results and thus to decrease the peak values, particularly in areas with strong spatial horizontal gradients. Besides, most of the time the wave model results are only calibrated ("assimilated") using of data from altimeter satellites, whose timing and location is uncorrelated with the weather or the sea state, so the calibration is biased against extreme weather or sea states.

It must also be noted here [14] that the scatter of results for wind velocity is always larger than for waves: this implies that the atmospheric variability [15] is the basic reason for the differences between model and experimental extreme data.

Another important aspect is the bias in the evaluation of extremes present in all sources of data whenever the sampling of the relevant parameter (SWH in our case) is carried out with too long a time interval compared with the inherent time constant of the phenomenon. The results shown for instance in $[10,16]$, prove that use of data with a low time resolution (such as a 3 or $6 \mathrm{~h}$ ) causes a considerable undervaluation of the extreme SWH values for a given return time $T_{R}$. The following Figure 1 [16] illustrates this point-by degrading the original buoy data from a sampling rate of $30^{\prime}$ (full data set) to a sampling rate of $6 \mathrm{~h}$, there is an important reduction of the estimated $\mathrm{H}_{S}\left(\mathrm{~T}_{R}\right)$. This raises the problem of deciding what would be the "right" interval to choose in order to compute the $H_{S}\left(T_{R}\right)$ curves. Current engineering practice is oriented towards $30^{\prime}$ or $1 \mathrm{~h}$ intervals, mostly because that is the commonly available sampling rate for buoy data, but also because what is normally important is not the extreme single wave, but some kind of average wave height; after all, this is the reason for adopting the concept of "significant wave height". The opportunity of this choice seems to be confirmed by the apparent convergence of the curves ( $1 \mathrm{~h}$ curve in blue is very close to the $30^{\prime}$ curve in red).

Investigating the use of even shorter sampling rates would lead to a different problem, i.e., the determination of the probability of single extreme waves: an issue which also has relevance, but seems to be not yet clarified, see for instance [17].

As a consequence of all this, the main problem in ocean and coastal engineering is that while long series of model data are available practically everywhere, the quality of such data is inadequate for the purpose of evaluating extreme SWHs; on the other hand, measurements taken at buoy wave meters provide reliable data, but for a limited number of sites.

The objective of this work is to propose a procedure by which model data can be integrated with experimental data in order to provide a better estimate of extreme SWH values. This is done by considering model-derived data at a given location as estimators-in a statistical sense- of the true values; and, in order to improve the estimate as well as to evaluate the error, information on their statistical distribution is obtained by analyzing the wave buoy data series in the area. 
In the following such a procedure is discussed and applied to three different sea areas:

1. South Mediterranean Italian coast;

2. North Atlantic Spanish coast;

3. Gulf of Mexico.

Global or regional wave datasets are provided by different organizations, i.e., ECMWF (European Centre for Medium-Range Weather Forecasts) and NOAA (National Oceanic and Atmospheric Administration).

The NOAA National Center for Environmental Prediction (NCEP) developed the Climate Forecast System (CFS), a fully coupled model representing the interaction between the Earth's atmosphere, oceans, land and sea ice. A reanalysis of the sea and atmosphere state for the period of 1979-2009 has been conducted, resulting in the CFS Reanalysis (CFSR) dataset. Using the CFSR dataset, the NOAA Marine Modelling and Analysis Branch (MMAB) has produced a wave hindcast for the same period. The wave hindcast dataset has been generated using the WAVEWATCH III (WW3) model (v3.14) (NOAA/National Weather Service, College Park, MD, U.S.A.) and is suitable for use in climate studies. The wave model resolves 50 wave frequencies (from 0.035 to $0.963 \mathrm{~Hz}$ ) and 36 wave directions (directional resolution of $10^{\circ}$ ). Data are given at a three-hourly time resolution and are available both on a global grid (spatial resolution of $0.5^{\circ} \times 0.5^{\circ}$ ) and on 16 different regional nested grids with a variable spatial resolution.

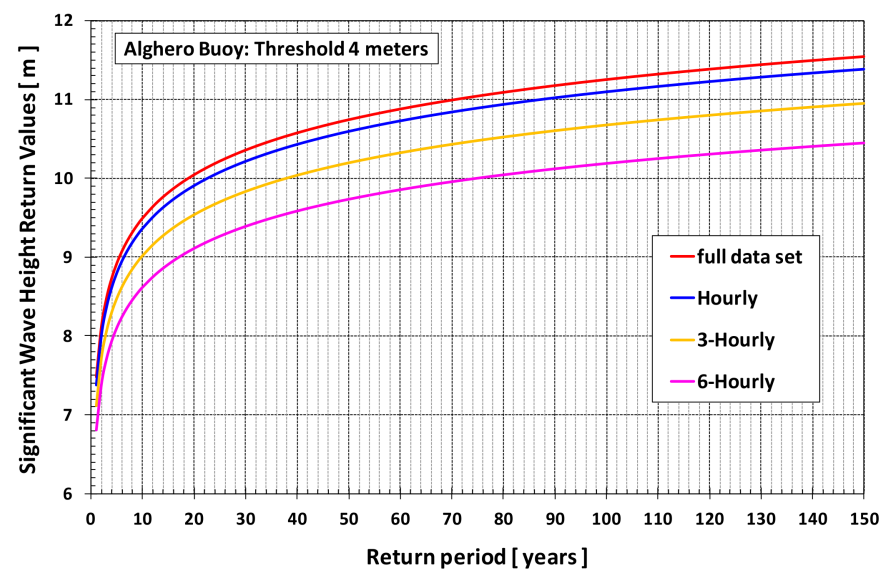

Figure 1. Effect of the varying sampling rate on the SWH extreme values.

The ECMWF produces the ERA-Interim dataset, another global atmospheric reanalysis dataset starting from 1979 and continuously updated. It also models oceanographic variables, including waves. The wave model used by ECMWF is based on the WAM (WAve Model) approach [18], resolving 30 wave frequencies and 24 wave directions. Furthermore, the wave model contains corrections for treating unresolved bathymetry effects and a reformulation of the dissipation source term. ERA-Interim produces four analysis data per day (at 00:00, 06:00, 12:00 and 18:00 UTC) and two 10-day forecast data per day, initialized from analysis at 00:00 and 12:00 UTC. Both wave products are distributed on a global $1.0^{\circ} \times 1.0^{\circ}$ latitude/longitude grid .

Many commercial companies provide a model series with smaller sampling intervals, and often with a finer spatial resolution; however only NOAA and ECMWW provide well-tested and public reanalysis data, so in the following only those two sources have been considered.

\section{Considered Datasets}

Six-hour ECMWF ERA-Interim re-analysis data were used throughout the work. However, since in two locations (South Mediterranean Italian coasts and Gulf of Mexico) NOAA data with adequate resolution are also available, these have been added to provide additional elements. 


\subsection{South Mediterranean Italian Coasts}

Direct data for this area are from the six Italian Data Buoy Network (RON) buoys reported in Figure 2.

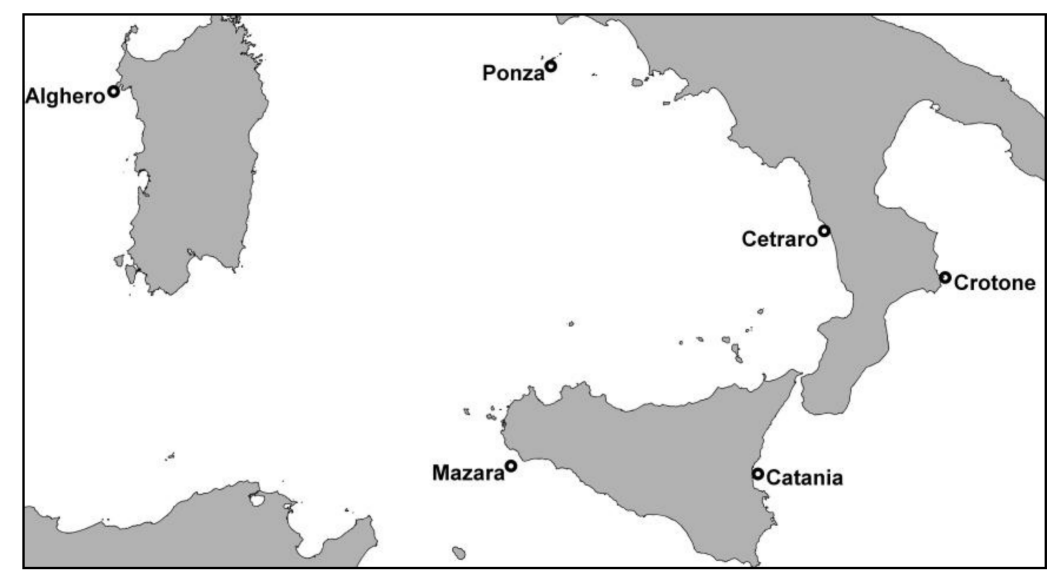

Figure 2. Position of the six considered Italian buoys-(RON).

More specific details about RON can be found in [6]. Table 1 reports the exact location and dataset time extension for the six considered buoys.

Table 1. South Mediterranean Italian coast: position, data sampling and dataset time extension for the different data sources considered.

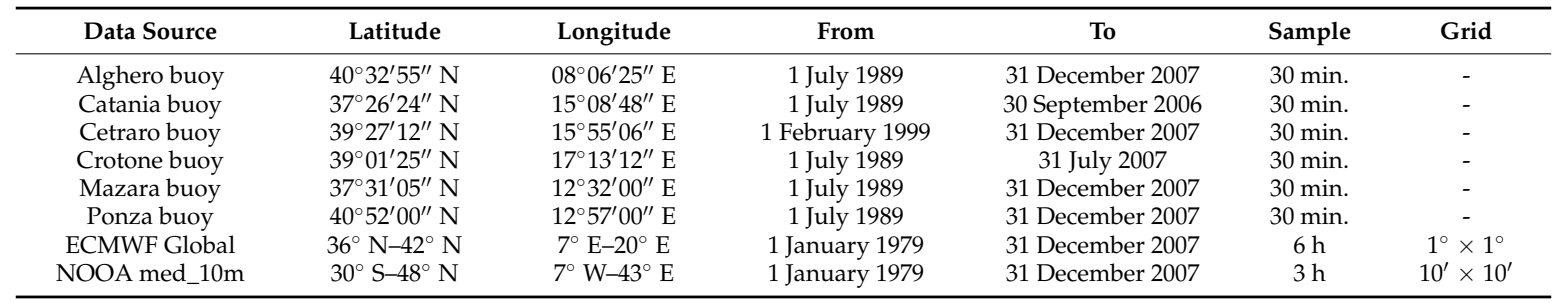

For indirect data, both the global six-hour analysis ECMWF ERA-Interim and the Mediterranean (med_10m) nested grid three-hourly NOAA-MMAB products were used. The former, provided on a $1^{\circ} \times 1^{\circ}$ latitude/longitude grid, were acquired for an area between $36^{\circ} \mathrm{N}-42^{\circ} \mathrm{N}$ of latitude and $7^{\circ} \mathrm{E}-20^{\circ} \mathrm{E}$ of longitude; the latter, on a $10^{\prime} \times 10^{\prime}$ (about $0.167^{\circ} \times 0.167^{\circ}$ ) latitude/longitude grid, cover an area between $30^{\circ} \mathrm{S}-48^{\circ} \mathrm{N}$ of latitude and $7^{\circ} \mathrm{W}-43^{\circ} \mathrm{E}$ of longitude (see Table 1 ).

\subsection{North Atlantic Spanish Coast}

For this area, direct data were sampled from the five buoys reported in Figure 3. The exact buoy location and relative dataset time extension are reported in Table 2.

Table 2. North Atlantic Spanish coast: position, data sampling and dataset time extension for the different data sources considered.

\begin{tabular}{|c|c|c|c|c|c|c|}
\hline Data Source & Latitude & Longitude & From & To & Sample & Grid \\
\hline C. De Penhas buoy & $43^{\circ} 45^{\prime} 00^{\prime \prime} \mathrm{N}$ & $06^{\circ} 09^{\prime} 36^{\prime \prime} \mathrm{W}$ & 1 January 1998 & 30 November 2010 & $1 \mathrm{~h}$ & - \\
\hline Estaca Bares buoy & $44^{\circ} 07^{\prime} 12^{\prime \prime} \mathrm{N}$ & $07^{\circ} 40^{\prime} 12^{\prime \prime} \mathrm{W}$ & 1 January 1998 & 31 August 2010 & $1 \mathrm{~h}$ & - \\
\hline Villano Sisar. buoy & $43^{\circ} 30^{\prime} 00^{\prime \prime} \mathrm{N}$ & $09^{\circ} 12^{\prime} 36^{\prime \prime} \mathrm{W}$ & 12 May 1998 & 30 November 2010 & $1 \mathrm{~h}$ & - \\
\hline ECMWF Global & $40^{\circ} \mathrm{N}-46^{\circ} \mathrm{N}$ & $12^{\circ} \mathrm{W}-2^{\circ} \mathrm{W}$ & 1 January 1998 & 31 December 2010 & $6 \mathrm{~h}$ & $1^{\circ} \times 1^{\circ}$ \\
\hline
\end{tabular}




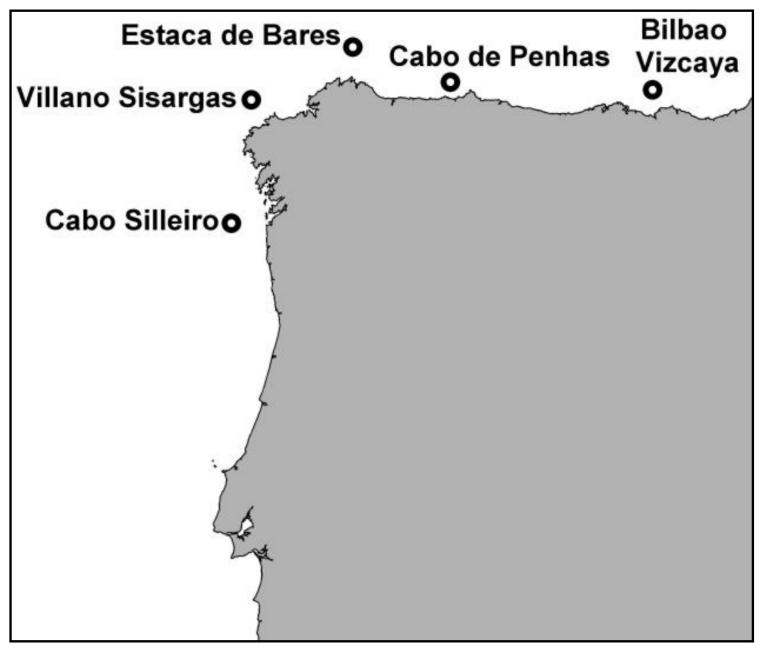

Figure 3. Buoy positions along the North Atlantic Spanish coast.

ECMWF ERA-Interim (global four analyses per day) indirect data were used. They are provided on a $1^{\circ} \times 1^{\circ}$ latitude/longitude grid and were acquired for an area between $40^{\circ} \mathrm{N}-46^{\circ} \mathrm{N}$ and $12^{\circ} \mathrm{W}-2^{\circ} \mathrm{W}$ of longitude (see Table 2 ).

\subsection{Gulf of Mexico}

Direct data were collected at seven National Data Buoy Center (NDBC) buoys whose locations are shown in Figure 4 and Table 3. Table 3 also reports the dataset time span for each buoy.

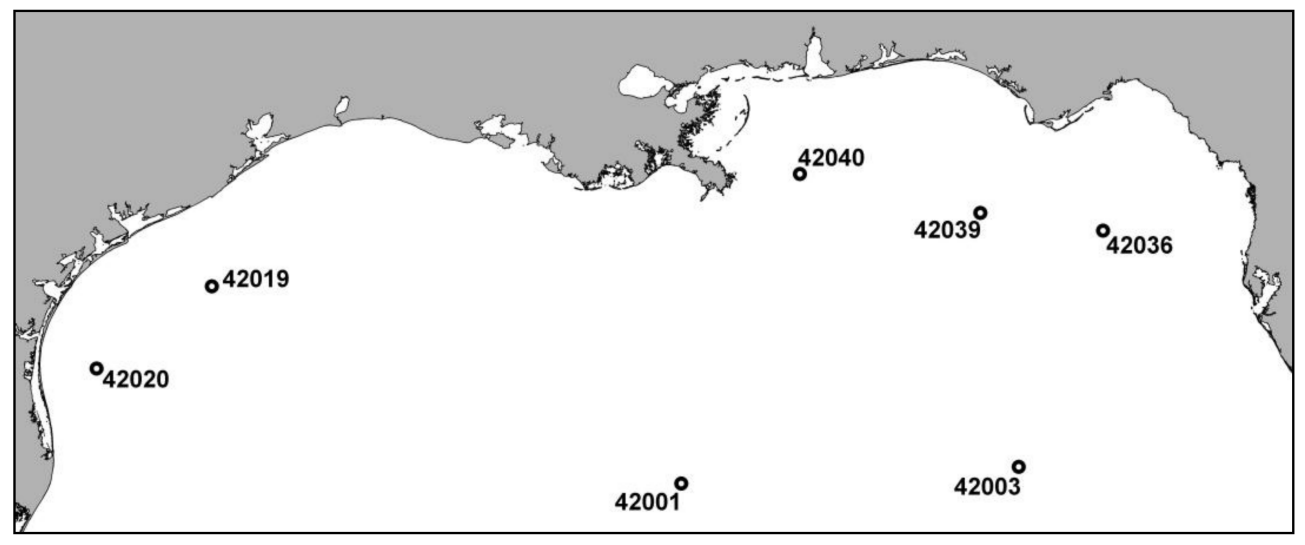

Figure 4. Position of seven NDBC buoys in the Gulf of Mexico.

Table 3. Gulf of Mexico: position, data sampling and dataset time extension for the different data sources considered.

\begin{tabular}{|c|c|c|c|c|c|c|}
\hline Data Source & Latitude & Longitude & From & To & Sample & Grid \\
\hline 42001 buoy & $25^{\circ} 53^{\prime} 48^{\prime \prime} \mathrm{N}$ & $89^{\circ} 40^{\prime} 06^{\prime \prime} \mathrm{W}$ & 1 March 1979 & 31 December 2007 & $1 \mathrm{~h}$ & - \\
\hline 42003 buoy & $26^{\circ} 00^{\prime} 25^{\prime \prime} \mathrm{N}$ & $85^{\circ} 38^{\prime} 54^{\prime \prime} \mathrm{W}$ & 1 January 1979 & 31 December 2007 & $1 \mathrm{~h}$ & - \\
\hline 42019 buoy & $27^{\circ} 54^{\prime} 24^{\prime \prime} \mathrm{N}$ & $95^{\circ} 21^{\prime} 09^{\prime \prime} \mathrm{W}$ & 1 May 1990 & 31 December 2007 & $1 \mathrm{~h}$ & - \\
\hline 42020 buoy & $26^{\circ} 58^{\prime} 04^{\prime \prime} \mathrm{N}$ & $96^{\circ} 41^{\prime} 39^{\prime \prime} \mathrm{W}$ & 1 May 1990 & 31 December 2007 & $1 \mathrm{~h}$ & - \\
\hline 42036 buoy & $28^{\circ} 30^{\prime} 03^{\prime \prime} \mathrm{N}$ & $84^{\circ} 30^{\prime} 56^{\prime \prime} \mathrm{W}$ & 1 January 1994 & 31 December 2007 & $1 \mathrm{~h}$ & - \\
\hline 42039 buoy & $28^{\circ} 47^{\prime} 18^{\prime \prime} \mathrm{N}$ & $86^{\circ} 00^{\prime} 31^{\prime \prime} \mathrm{W}$ & 1 December 1995 & 31 December 2007 & $1 \mathrm{~h}$ & - \\
\hline 42040 buoy & $29^{\circ} 12^{\prime} 30^{\prime \prime} \mathrm{N}$ & $88^{\circ} 13^{\prime} 33^{\prime \prime} \mathrm{W}$ & 1 December 1995 & 31 December 2007 & $1 \mathrm{~h}$ & - \\
\hline ECMWF Global & $24^{\circ} \mathrm{N}-32^{\circ} \mathrm{N}$ & $100^{\circ} \mathrm{W}-80^{\circ} \mathrm{W}$ & 1 January 1979 & 31 December 2007 & $6 \mathrm{~h}$ & $1^{\circ} \times 1^{\circ}$ \\
\hline NOOA ecg_10m & $0^{\circ} \mathrm{N}-55^{\circ} \mathrm{N}$ & $100^{\circ} \mathrm{W}-50^{\circ} \mathrm{W}$ & 1 January 1979 & 31 December 2007 & $3 \mathrm{~h}$ & $10^{\prime} \times 10$ \\
\hline
\end{tabular}

ECMWF ERA-Interim were considered as well as NOAA-MMAB. The former were acquired for an area between $24^{\circ} \mathrm{N}-32^{\circ} \mathrm{N}$ of latitude and $100^{\circ} \mathrm{W}-80^{\circ} \mathrm{W}$ of longitude on a grid of $1^{\circ} \times 1^{\circ}$, the latter, 
in particular, were acquired from the Gulf of Mexico and NW Atlantic (ecg_10m) nested grid that covers an area between $0^{\circ} \mathrm{N}-55^{\circ} \mathrm{N}$ of latitude and $100^{\circ} \mathrm{W}-50^{\circ} \mathrm{W}$ of longitude with a $10^{\prime} \times 10^{\prime}$ (about $0.167^{\circ} \times 0.167^{\circ}$ ) spatial resolution.

\section{Methods}

As stated above, substantial differences can be found when performing an EVA considering directly observed and indirect wave data. Therefore, for practical coastal engineering purposes a procedure is necessary to correct and to evaluate the reliability of $\mathrm{H}_{S}\left(\mathrm{~T}_{R}\right)$ curves derived from model data for any location at sea. In the following, one such procedure is proposed and tested and shown to be reliable in areas where an adequate number of in situ wave buoys are available. Unlike most calibration or validation procedures currently being performed, all our elaborations were carried out on the $H_{S}\left(T_{R}\right)$ functions rather than on the single raw extreme recorded significant wave heights $H_{S}$. The basic concept is that the parameters of any $\mathrm{H}_{S}\left(\mathrm{~T}_{R}\right)$ function are themselves randomly distributed, and that the distribution of such parameters can be estimated by analyzing in situ data for any given area, thus providing a regional assessment of the error associated with such an estimate.

It is worth noting that the wave part of the model chain takes care of physical marine aspects such as fetch and depth, so that the difference between the data from the buoy and the data from the relevant model grid point depends partly on the meteorological uncertainty (i.e., the error of the wind part of the chain) and partly from the inherent error of the wave part of the model.

This approach is similar to what is done in many fields where distributed data (from a model or from a remote sensor) need to be assimilated and corrected with field data. In hydrology, for example, regional models for hydro-meteorological variables, such as extreme or annual rainfall, are often obtained by coupling a deterministic indicator, based on models, with a spatial model of the residuals measured at gauged sites [19-22]. A similar approach is also used for extracting the estimated rainfall rate at ground through meteorological radars and rain gauge measurements $[23,24]$. Several methods have been introduced to this purpose [23-27]. In all such procedures, a regional assessment of statistical uncertainty is carried out by making use of spatial estimates of the error distributions.

For SWH extremes, the limited information coming from the historical data can be largely compensated by the available indirect model archive data. In order to do so, in this work the model data are used as indicators, and the buoy data are used for the correction of biases and the evaluation of uncertainties.

Extreme $\mathrm{SWH}$ values $\mathrm{HM}\left(\mathrm{T}_{\mathrm{R}}\right)$ derived from model (indirect) time series are thus integrated with extreme $S W H$ values $H D\left(T_{R}\right)$ derived from whatever wave buoy (direct) time series available in the same geographical area. This provides a tool to derive an estimated function $\mathrm{H}_{S}\left(\mathrm{~T}_{R}\right)$ for any point in the area, as well as an assessment of the quality of the whole model chain.

There are many possible alternatives which can be selected for this purpose-a first important decision to be taken is whether the observation period upon which the parameters are estimated should be the same for both the model and the wave buoy, or should encompass the whole length of the available period of observed or modeled data. On the one hand, for the sake of consistency, the time spans of the observation should coincide; on the other hand, since the final scope of the work is to provide a reliable tool, it would instead make sense to compare all the available in situ data with all the available model data (normally, the simulated data series are much longer than the experimental ones). As stated above, in the present paper, since the objective is to illustrate a procedure in the simplest possible way, the first alternative has been pursued so the series considered for each location overlap as much as possible.

A further choice is the actual threshold value to adopt if a POT (peak over threshold) procedure is used to compute the $\operatorname{HD}\left(\mathrm{T}_{\mathrm{R}}\right)$ and $\operatorname{HM}\left(\mathrm{T}_{\mathrm{R}}\right)$ functions. In this work, among the various possible alternatives, the thresholds were chosen by making sure that the number $\mathrm{N}_{\mathrm{T}}$ of extreme events considered would be roughly equal for all the samples. Obviously, $\mathrm{N}_{\mathrm{T}}$ increases by decreasing the threshold because more events are taken into account; on the other hand, if the threshold is too low the 
quality of the estimate is compromised, since the events will no longer be statistically independent. A compromise has to be found, and a measure of such compromise is given by the value of the parameter $\lambda=\mathrm{N}_{\mathrm{T}} / n, n$ being the number of available observation years. This procedure is normally adopted in coastal engineering activities [28] and is meant to provide a higher number of extremes, compared with annual maxima.

In any case, since the present paper is not aimed at evaluating, discussing or recommending one particular form of $\mathrm{H}_{S}\left(\mathrm{~T}_{R}\right)$, or any particular procedure to estimate its parameters, the only requirement is that such a form and procedure should be uniform throughout the whole analysis.

In the following, the peak over threshold (POT) method in the form described for instance in [29-33] was followed to produce a set of extreme significant wave height values. There is here a choice to be made as to which extreme value distribution should be fitted to the data. For instance [34,35] suggest that a GPD (generalized Pareto distribution) should be employed for EVA. However, according to current ocean engineering practice [28,36], the Weibull distribution was adopted (Equation (1)):

$$
\mathrm{F}\left(\mathrm{H}_{\mathrm{S}}\right)=1-\exp \left\{-\left[\left(\mathrm{H}_{\mathrm{S}}-\mathrm{B}\right) / \mathrm{A}\right]^{\mathrm{k}}\right\},
$$

where A, B and $\mathrm{k}$ are known respectively as scale, position and shape parameters. Once the distribution parameters are known, the $H_{S}$ return value for a given return period $T_{R}$ (in years) is computed by making use of Equation (2):

$$
\mathrm{H}_{\mathrm{S}}\left(\mathrm{T}_{\mathrm{R}}\right)=\mathrm{B}+\mathrm{A}\left[\ln \left(\lambda \mathrm{T}_{\mathrm{R}}\right)\right]^{1 / \mathrm{k}}
$$

The $\lambda T_{R}$ term derives from the POT techniques, where $\lambda$ extreme values are considered on average for each observation year.

The same operation is carried out with both historical experimental direct datasets $\operatorname{HD}\left(\mathrm{T}_{\mathrm{R}}\right)$ and indirect data $\mathrm{HM}\left(\mathrm{T}_{\mathrm{R}}\right)$ at the same locations-naturally most of the time the positions do not exactly coincide with model grid points, so a spatial bi-linear interpolation (co-location) as described in [37] (pp. 10-11) has to be carried out. As shown in Figure 5, for the four model grid points (black crosses) around each buoy location (filled red circle), a linear interpolation (red circles) between each pair of grid points has been computed. These two, in either the latitudinal or longitudinal direction, have then been used for linear interpolation to the requested boy location (filled red circle).

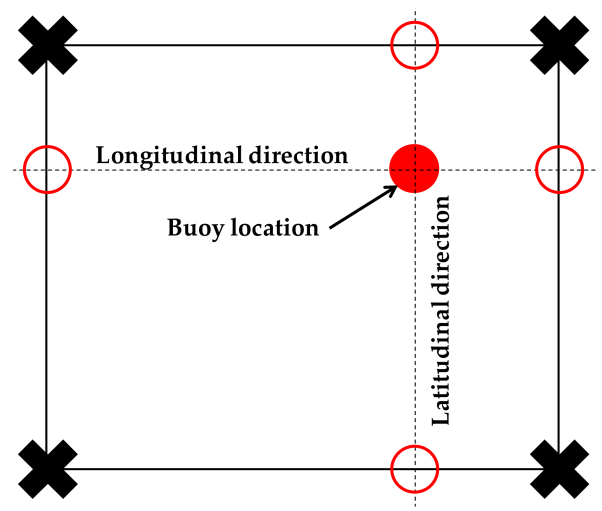

Figure 5. Scheme of bi-linear spatial interpolation of the four model grid points (black crosses) to the requested buoy location (filled red circle). First a linear interpolation (red circles) between each pair of grid points is computed; then a further linear interpolation between these points, in either the latitudinal or longitudinal direction, provides the value to the requested position.

Since wave buoy time series are often incomplete, the experimental and model data series cannot be made to coincide exactly; some care must thus be taken to make sure that the extent of time they refer to are not too far apart. The mean rate values $\lambda$ for the indirect data has been kept close enough to the $\lambda$ value of the in-situ data, which generally means adopting a lower threshold. 
Once the experimental $\mathrm{HD}\left(\mathrm{T}_{\mathrm{R}}\right)$ and the model-derived $\mathrm{HM}\left(\mathrm{T}_{\mathrm{R}}\right)$ curves have been computed, no matter how good the data or how careful their elaboration is, they will certainly differ for the reasons stated above.

In the following Figure 6, the results are shown for a test carried out in the three sea regions.
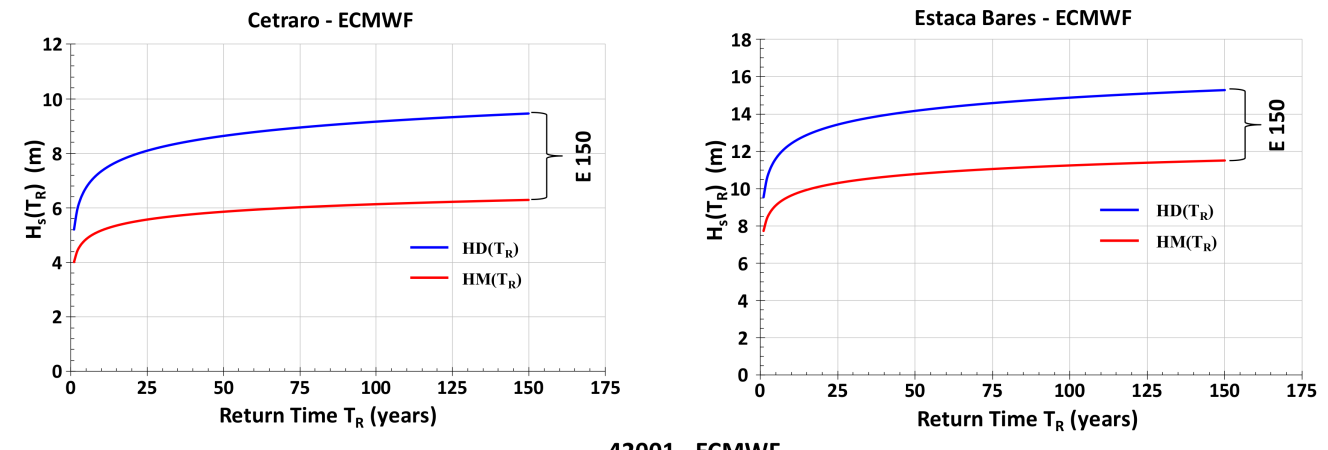

42001 - ECMWF

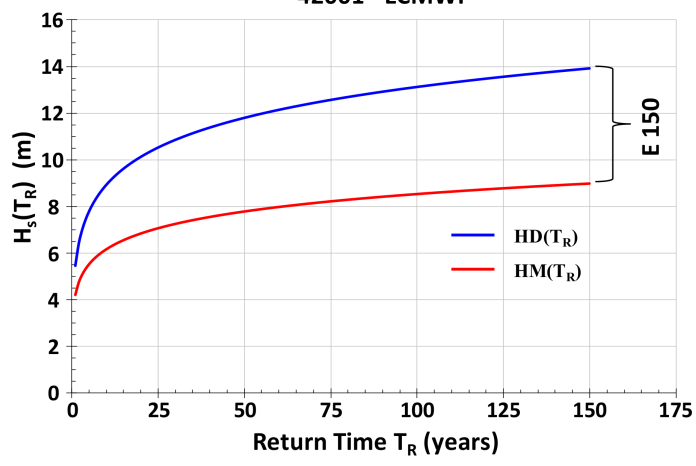

Figure 6. $\mathrm{HD}\left(\mathrm{T}_{\mathrm{R}}\right)$ values computed with direct (blue curves) and indirect (red curves) data for various buoy location.

Models generally underestimate extreme values compared to experimental data, partly due to the inevitable smoothing of the results due to the numerical interpolation, and partly due to inherent limitations of the model chain, as it was shown quantitatively in [13-16]. As a consequence, it is to be expected for a given return time $T_{R}$ that the corresponding significant wave height return value computed with the indirect data $\operatorname{HM}\left(\mathrm{T}_{R}\right)$ is lower than the value obtained by making use of direct data $\operatorname{HD}\left(\mathrm{T}_{\mathrm{R}}\right)$.

The $\operatorname{HM}\left(T_{R}\right)$ values are then assumed to be indicators of the unknown true values, and a statistical correlation must thus be found between $\operatorname{HM}\left(T_{R}\right)$ and $\operatorname{HD}\left(T_{R}\right)$ in order to provide a reliable estimator $\mathrm{H}_{\mathrm{S}}\left(\mathrm{T}_{\mathrm{R}}\right)$. We have then [22]:

$$
H_{S}\left(T_{R}\right)=H M\left(T_{R}\right)+H M\left(T_{R}\right) \cdot e(\mu, \sigma),
$$

$\mathrm{e}(\mu, \sigma)$ being the relative error distribution.

Following Equation (3), the expected values $\mathrm{H}_{S}$ for each $\mathrm{T}_{R}$ are:

$$
\mathrm{H}_{\mathrm{S}}\left(\mathrm{T}_{\mathrm{R}}\right)=\mathrm{HM}\left(\mathrm{T}_{\mathrm{R}}\right)+\mu \cdot \mathrm{HM}\left(\mathrm{T}_{\mathrm{R}}\right)
$$

and its upper and lower bounds of the $95 \%$ confidence intervals, corresponding at the $97.5 \%$ an $2.5 \%$ percentiles, are respectively:

$$
H_{S}\left(T_{R}\right)=H M\left(T_{R}\right)+\mu\left(T_{R}\right) \cdot H M\left(T_{R}\right) \pm 2 \sigma\left(T_{R}\right) \cdot H M\left(T_{R}\right),
$$

$\mathrm{e}(\mu, \sigma)$ represents the error caused by many reasons: meteorological uncertainty, model inaccuracy, and, as often happens, the different sampling rate between the experimental and the model data. The value 
of the parameters $\mu$ and $\sigma$ can be evaluated by making use of a spatial analysis, i.e., by comparing the model result $H M_{i}\left(T_{R}\right)$ with the experimental $H_{i}\left(T_{R}\right)$ values at the buoy location $i$ of the $m$ buoys available in the area. The relative error $e_{i}\left(T_{R}\right)$ at location $i$ is then given by Equation (6):

$$
\mathrm{e}_{\mathrm{i}}\left(\mathrm{T}_{\mathrm{R}}\right)=\left[\mathrm{HD}_{\mathrm{i}}\left(\mathrm{T}_{\mathrm{R}}\right)-\mathrm{HM}_{\mathrm{i}}\left(\mathrm{T}_{\mathrm{R}}\right)\right] / \mathrm{HM}_{\mathrm{i}}\left(\mathrm{T}_{\mathrm{R}}\right)
$$

Its expected value $\mu\left(T_{R}\right)$ can be estimated as:

$$
\mu\left(\mathrm{T}_{\mathrm{R}}\right)=\frac{1}{\mathrm{~m}} \sum_{\mathrm{i}=1}^{\mathrm{m}} \mathrm{e}_{\mathrm{i}}
$$

and its root mean square $\sigma\left(\mathrm{T}_{\mathrm{R}}\right)$ as

$$
\sigma\left(T_{R}\right)=\sqrt{\frac{1}{m-1} \sum_{i=1}^{m}\left(e_{i}-\mu\right)^{2}}
$$

the sums over the index $\mathrm{i}$ being extended to the $\mathrm{m}$ wave buoys in the region.

These estimates can be used to quantify the accuracy of the model chain, as well as to provide a way to compute $\mathrm{H}_{S}\left(\mathrm{~T}_{\mathrm{R}}\right)$ curves for geographical locations not coinciding with wave buoys by making use of Equation (4), and of the standard deviation $\sigma\left(\mathrm{T}_{\mathrm{R}}\right)$ given by Equation (8).

Figure 7 reports some examples. Curves $H_{S}\left(T_{R}\right)$ are shown together with the $\sigma_{68}$ and $\sigma_{96}$ confidence interval curves respectively equal to:

$$
\begin{gathered}
H_{68}=H_{S}\left(T_{R}\right) \pm \sigma\left(T_{R}\right) \cdot H_{S}\left(T_{R}\right) \\
H_{96}=H_{S}\left(T_{R}\right) \pm 2 \sigma\left(T_{R}\right) \cdot H_{S}\left(T_{R}\right)
\end{gathered}
$$
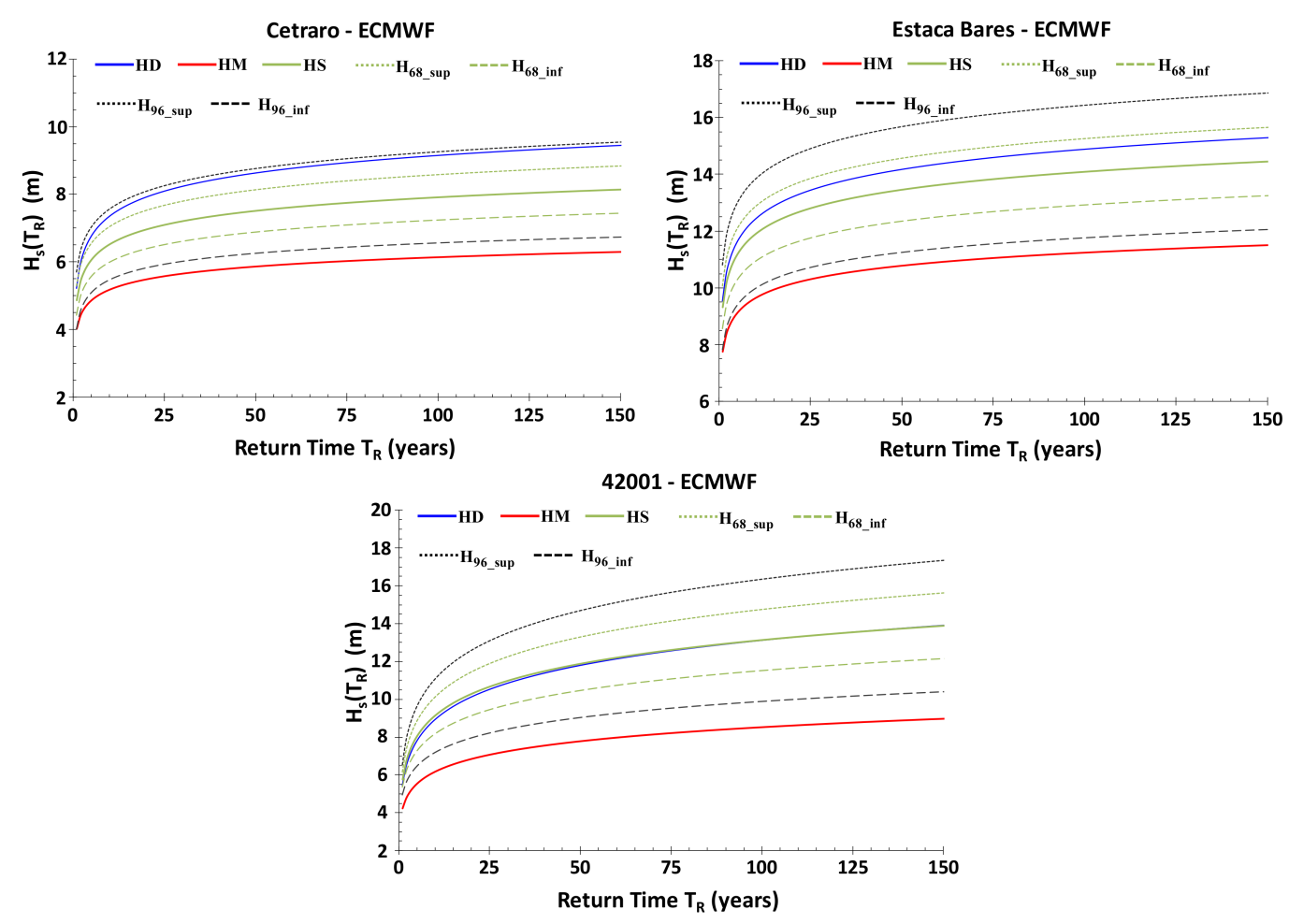

Figure 7. $\mathrm{H}_{\mathrm{S}}\left(\mathrm{T}_{\mathrm{R}}\right)$ curves for direct $(\mathrm{HD})$ and indirect $(\mathrm{HM})$ data for various locations with $\sigma_{68}$ and $\sigma_{96}$ confidence intervals. 
Similar analyses have been carried out for the three regions, and the results are reported in the following section.

\section{Results}

The computations were separately carried out as described above for all the buoys in each of the three regions. The buoys in each region are close enough to be considered similar from a meteorological point of view; it is also worth noting that in one of the regions (Southern Italian coast) the position of each of the buoys with respect to the coast are very different from each other.

\subsection{South Mediterranean Italian Coasts}

The dataset extension, threshold and mean rate values both for direct and indirect data relative to each location are reported in Table 4. The NOAA model data are included only as a comparison and were not used in the estimation procedure.

Table 4. South Mediterranean Italian coast: data relevant to each location for direct (buoy) and the corresponding co-located indirect (model) datasets.

\begin{tabular}{|c|c|c|c|c|c|c|c|c|}
\hline Source & Location & From & To & Sample & $\begin{array}{c}\text { Threshold } \\
\text { (m) }\end{array}$ & $\mathbf{N}_{\mathrm{t}}$ & $\begin{array}{l}\text { Years } \\
(n)\end{array}$ & $\lambda$ \\
\hline \multirow{6}{*}{ Buoy } & Alghero & 1 July 1989 & 31 December 2007 & $30^{\prime}$ & 5.00 & 143 & 16.92 & 8.45 \\
\hline & Catania & 1 July 1989 & 30 September 2006 & $30^{\prime}$ & 2.50 & 83 & 14.90 & 5.57 \\
\hline & Cetraro & 1 February 1999 & 31 December 2007 & $30^{\prime}$ & 3.00 & 52 & 7.58 & 6.86 \\
\hline & Crotone & 1 July 1989 & 31 July 2007 & $30^{\prime}$ & 3.00 & 105 & 16.34 & 6.43 \\
\hline & Mazara & 1 July 1989 & 31 December 2007 & $30^{\prime}$ & 3.50 & 109 & 15.55 & 7.01 \\
\hline & Ponza & 1 July 1989 & 31 December 2007 & $30^{\prime}$ & 3.50 & 94 & 15.95 & 5.89 \\
\hline \multirow{6}{*}{ ECMWF } & Alghero & 1 July 1989 & 31 December 2007 & $6 \mathrm{~h}$ & 4.00 & 117 & 18.5 & 6.32 \\
\hline & Catania & 1 July 1989 & 30 September 2006 & $6 \mathrm{~h}$ & 3.00 & 81 & 17.25 & 4.70 \\
\hline & Cetraro & 1 February 1999 & 31 December 2007 & $6 \mathrm{~h}$ & 3.00 & 39 & 8.92 & 4.37 \\
\hline & Crotone & 1 July 1989 & 31 July 2007 & $6 \mathrm{~h}$ & 3.00 & 91 & 18.08 & 5.03 \\
\hline & Mazara & 1 July 1989 & 31 December 2007 & $6 \mathrm{~h}$ & 3.00 & 116 & 18.5 & 6.27 \\
\hline & Ponza & 1 July 1989 & 31 December 2007 & $6 \mathrm{~h}$ & 3.00 & 82 & 18.5 & 4.43 \\
\hline \multirow{6}{*}{ NOAA } & Alghero & 1 July 1989 & 31 December 2007 & $3 \mathrm{~h}$ & 4.50 & 106 & 18.5 & 5.73 \\
\hline & Catania & 1 July 1989 & 30 September 2006 & $3 \mathrm{~h}$ & 2.00 & 68 & 17.25 & 3.94 \\
\hline & Cetraro & 1 February 1999 & 31 December 2007 & $3 \mathrm{~h}$ & 3.00 & 47 & 8.92 & 5.27 \\
\hline & Crotone & 1 July 1989 & 31 July 2007 & $3 \mathrm{~h}$ & 3.00 & 76 & 18.08 & 4.20 \\
\hline & Mazara & 1 July 1989 & 31 December 2007 & $3 \mathrm{~h}$ & 3.50 & 105 & 18.5 & 5.68 \\
\hline & Ponza & 1 July 1989 & 31 December 2007 & $3 \mathrm{~h}$ & 3.00 & 114 & 18.5 & 6.16 \\
\hline
\end{tabular}

Results are shown in Tables 5 and 6 (respectively for the ECMWF and NOAA model data), which report the various parameters of the curves for all the buoy locations in the area.

Table 5. South Mediterranean Italian coast: comparison between buoy (HD), ECMWF model (HM) and estimated $\left(\mathrm{H}_{\mathrm{S}}\right)$ significant wave height for various values of the return period $\mathrm{T}_{\mathrm{R}}$.

\begin{tabular}{cccccccccccccc}
\hline $\begin{array}{c}\mathbf{T}_{\mathbf{R}} \text { and Related } \\
\boldsymbol{\sigma} \text { Values }\end{array}$ & \multicolumn{3}{c}{$\mathbf{T}_{\mathbf{R}}=\mathbf{2 5}$ Years } & \multicolumn{3}{c}{$\mathbf{T}_{\mathbf{R}}=\mathbf{5 0}$ Years } & \multicolumn{3}{c}{$\mathbf{T}_{\mathbf{R}}=\mathbf{7 5}$ Years } & \multicolumn{3}{c}{$\mathbf{T}_{\mathbf{R}}=\mathbf{1 0 0}$ Years } \\
\cline { 2 - 15 } & \multicolumn{3}{c}{$\boldsymbol{\sigma}=\mathbf{0 . 1 0 4 3}$} & \multicolumn{3}{c}{$\boldsymbol{\sigma}=\mathbf{0 . 1 0 7 0}$} & \multicolumn{3}{c}{$\boldsymbol{\sigma}=\mathbf{0 . 1 0 8 7}$} & \multicolumn{2}{c}{$\boldsymbol{\sigma}=\mathbf{0 . 1 1 0 0}$} \\
\hline Location & $\mathbf{H D}$ & $\mathbf{H M}$ & $\mathbf{H}_{\mathbf{S}}$ & $\mathbf{H D}$ & $\mathbf{H M}$ & $\mathbf{H}_{\mathbf{S}}$ & $\mathbf{H D}$ & $\mathbf{H M}$ & $\mathbf{H}_{\mathbf{S}}$ & $\mathbf{H D}$ & $\mathbf{H M}$ & $\mathbf{H}_{\mathbf{S}}$ \\
\hline Alghero & 9.9 & 7.2 & 9.2 & 10.3 & 7.5 & 9.7 & 10.6 & 7.7 & 9.9 & 10.8 & 7.9 & 10.1 \\
Catania & 6.3 & 5.3 & 6.8 & 6.7 & 5.6 & 7.1 & 6.9 & 5.7 & 7.4 & 7.1 & 5.8 & 7.5 \\
Cetraro & 8.1 & 5.6 & 7.1 & 8.6 & 5.9 & 7.5 & 8.9 & 6.0 & 7.7 & 9.2 & 6.1 & 7.9 \\
Crotone & 6.5 & 5.3 & 6.8 & 6.8 & 5.6 & 7.1 & 7.0 & 5.7 & 7.3 & 7.1 & 5.8 & 7.5 \\
Mazara & 7.0 & 6.0 & 7.6 & 7.3 & 6.3 & 8.0 & 7.5 & 6.4 & 8.2 & 7.6 & 6.5 & 8.4 \\
Ponza & 6.9 & 5.5 & 7.0 & 7.3 & 5.8 & 7.5 & 7.5 & 6.0 & 7.7 & 7.7 & 6.1 & 7.9 \\
\hline
\end{tabular}


Table 6. South Mediterranean Italian coast: comparison between buoy (HD), NOAA model (HM) and estimated $\left(\mathrm{H}_{\mathrm{S}}\right)$ significant wave height for various values of the return period $T_{R}$.

\begin{tabular}{|c|c|c|c|c|c|c|c|c|c|c|c|c|}
\hline \multirow{3}{*}{$\begin{array}{c}\begin{array}{c}T_{R} \text { and Related } \\
\sigma \text { Values }\end{array} \\
\text { Location }\end{array}$} & \multirow{2}{*}{\multicolumn{3}{|c|}{$\begin{array}{c}T_{R}=25 \text { Years } \\
\sigma=0.0867\end{array}$}} & \multirow{2}{*}{\multicolumn{3}{|c|}{$\begin{array}{c}T_{R}=50 \text { Years } \\
\sigma=0.0893\end{array}$}} & \multirow{2}{*}{\multicolumn{3}{|c|}{$\begin{array}{c}T_{\mathrm{R}}=75 \text { Years } \\
\sigma=0.0908\end{array}$}} & \multirow{2}{*}{\multicolumn{3}{|c|}{$\begin{array}{c}T_{R}=100 \text { Years } \\
\sigma=0.0918\end{array}$}} \\
\hline & & & & & & & & & & & & \\
\hline & HD & HM & $\mathbf{H}_{\mathbf{S}}$ & HD & HM & $\mathrm{H}_{\mathrm{S}}$ & HD & HM & $\mathrm{H}_{\mathrm{S}}$ & HD & HM & $\mathbf{H}_{\mathrm{S}}$ \\
\hline Alghero & 9.9 & 7.4 & 8.9 & 10.3 & 7.7 & 9.3 & 10.6 & 7.9 & 9.5 & 10.8 & 8.0 & 9.6 \\
\hline Catania & 6.3 & 5.1 & 6.1 & 6.7 & 5.4 & 6.5 & 6.9 & 5.6 & 6.8 & 7.1 & 5.8 & 6.9 \\
\hline Cetraro & 8.1 & 6.6 & 7.9 & 8.6 & 7.0 & 8.4 & 8.9 & 7.2 & 8.7 & 9.2 & 7.4 & 8.9 \\
\hline Crotone & 6.5 & 6.2 & 7.4 & 6.8 & 6.5 & 7.8 & 7.0 & 6.7 & 8.1 & 7.1 & 6.8 & 8.2 \\
\hline Mazara & 7.0 & 6.1 & 7.3 & 7.3 & 6.3 & 7.6 & 7.5 & 6.5 & 7.8 & 7.6 & 6.6 & 7.9 \\
\hline Ponza & 6.9 & 5.8 & 6.9 & 7.3 & 6.1 & 7.3 & 7.5 & 6.2 & 7.5 & 7.7 & 6.4 & 7.6 \\
\hline
\end{tabular}

\subsection{North Atlantic Spanish Coast}

The dataset extension, threshold and mean rate values $\lambda$ both for direct and indirect data relative to each location are reported in Table 7.

Table 7. North Atlantic Spanish coast: data relevant to each location for direct (buoy) and the corresponding co-located indirect (model) datasets.

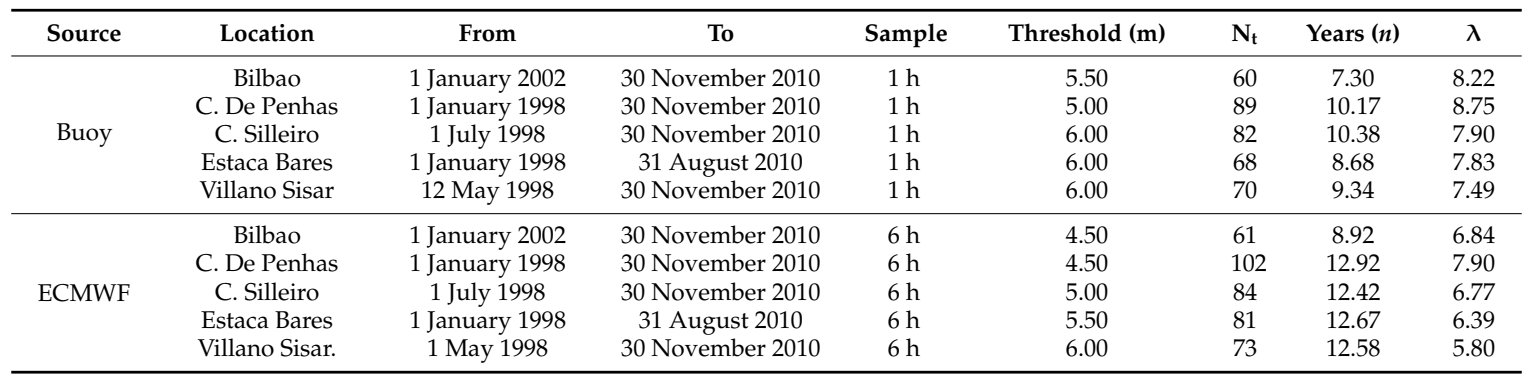

Results are shown in Table 8, which reports the various parameters of the curves for all the buoy locations in the area.

Table 8. North Atlantic Spanish coast: comparison between buoy (HD), ECMWF model (HM) and estimated $\left(\mathrm{H}_{\mathrm{S}}\right)$ significant wave height for various values of the return period $\mathrm{T}_{\mathrm{R}}$.

\begin{tabular}{|c|c|c|c|c|c|c|c|c|c|c|c|c|}
\hline \multirow{3}{*}{$\begin{array}{c}\begin{array}{c}T_{R} \text { and Related } \\
\sigma \text { Values }\end{array} \\
\text { Location }\end{array}$} & \multirow{2}{*}{\multicolumn{3}{|c|}{$\begin{array}{c}T_{R}=25 \text { Years } \\
\sigma=0.0741\end{array}$}} & \multirow{2}{*}{\multicolumn{3}{|c|}{$\begin{array}{c}T_{\mathrm{R}}=50 \text { Years } \\
\sigma=0.0753\end{array}$}} & \multirow{2}{*}{\multicolumn{3}{|c|}{$\begin{array}{c}T_{\mathrm{R}}=75 \text { Years } \\
\sigma=0.0760\end{array}$}} & \multirow{2}{*}{\multicolumn{3}{|c|}{$\begin{array}{c}T_{\mathrm{R}}=100 \text { Years } \\
\sigma=0.0765\end{array}$}} \\
\hline & & & & & & & & & & & & \\
\hline & HD & HM & $\mathbf{H}_{\mathbf{S}}$ & HD & HM & $\mathrm{H}_{\mathrm{S}}$ & HD & HM & $\mathbf{H}_{\mathrm{S}}$ & HD & HM & $\mathrm{H}_{\mathrm{S}}$ \\
\hline Bilbao & 14.0 & 10.2 & 12.7 & 14.8 & 10 & 13.5 & 15.3 & 11.1 & 14.0 & 15.6 & 11.4 & 14.3 \\
\hline C. De Penhas & 11.2 & 9.8 & 12.1 & 11.8 & 10.3 & 12.8 & 12.2 & 10.5 & 13.2 & 12.4 & 10.7 & 13.5 \\
\hline C. Silleiro & 12.5 & 9.5 & 11.8 & 13.1 & 9.9 & 12.4 & 13.5 & 10.2 & 12.7 & 13.8 & 10.3 & 13.0 \\
\hline Estaca Bares & 13.4 & 10.3 & 12.8 & 14.2 & 10.8 & 13.5 & 14.6 & 11.0 & 13.8 & 14.9 & 11.2 & 14.1 \\
\hline Villano Sisar. & 13.7 & 11.0 & 13.6 & 14.4 & 11.5 & 14.3 & 14.8 & 11.8 & 14.7 & 15.1 & 12.0 & 15.0 \\
\hline
\end{tabular}

\subsection{Gulf of Mexico}

Data relevant to each location for direct and indirect data are reported in the following Table 9. NOAA model data are included only as a comparison and have not been used in the estimation procedure. 
Table 9. Gulf of Mexico: data relevant to each location for direct (buoy) and the corresponding co-located indirect (model) datasets.

\begin{tabular}{|c|c|c|c|c|c|c|c|c|}
\hline Source & Location & From & To & Sample & Threshold (m) & $\mathbf{N}_{\mathrm{t}}$ & Years $(n)$ & $\lambda$ \\
\hline \multirow{7}{*}{ Buoy } & 42001 & 1 March 1979 & 31 December 2007 & $1 \mathrm{~h}$ & 3.50 & 187 & 26.28 & 7.12 \\
\hline & 42003 & 1 January 1979 & 31 December 2007 & $1 \mathrm{~h}$ & 3.50 & 158 & 24.50 & 6.45 \\
\hline & 42019 & 1 May 1990 & 31 December 2007 & $1 \mathrm{~h}$ & 3.50 & 119 & 14.83 & 8.02 \\
\hline & 42020 & 1 May 1990 & 31 December 2007 & $1 \mathrm{~h}$ & 3.50 & 116 & 14.49 & 8.01 \\
\hline & 42036 & 1 January 1994 & 31 December 2007 & $1 \mathrm{~h}$ & 3.50 & 81 & 11.83 & 6.85 \\
\hline & 42039 & 1 December 1995 & 31 December 2007 & $1 \mathrm{~h}$ & 3.50 & 87 & 11.51 & 7.56 \\
\hline & 42040 & 1 December 1995 & 31 December 2007 & $1 \mathrm{~h}$ & 3.50 & 66 & 11.51 & 5.73 \\
\hline \multirow{7}{*}{ ECMWF } & 42001 & 1 March 1979 & 31 December 2007 & $6 \mathrm{~h}$ & 3.00 & 200 & 28.83 & 6.94 \\
\hline & 42003 & 1 January 1979 & 31 December 2007 & $6 \mathrm{~h}$ & 3.00 & 179 & 29.00 & 6.17 \\
\hline & 42019 & 1 May 1990 & 31 December 2007 & $6 \mathrm{~h}$ & 3.00 & 60 & 17.67 & 3.40 \\
\hline & 42020 & 1 May 1990 & 31 December 2007 & $6 \mathrm{~h}$ & 3.00 & 100 & 17.67 & 5.66 \\
\hline & 42036 & 1 January 1994 & 31 December 2007 & $6 \mathrm{~h}$ & 3.00 & 77 & 14.00 & 5.50 \\
\hline & 42039 & 1 December 1995 & 31 December 2007 & $6 \mathrm{~h}$ & 3.00 & 53 & 12.08 & 4.39 \\
\hline & 42040 & 1 December 1995 & 31 December 2007 & $6 \mathrm{~h}$ & 3.00 & 49 & 12.08 & 4.06 \\
\hline \multirow{7}{*}{ NOAA } & 42001 & 1 March 1979 & 31 December 2007 & $3 \mathrm{~h}$ & 3.50 & 215 & 27.92 & 7.70 \\
\hline & 42003 & 1 January 1979 & 31 December 2007 & $3 \mathrm{~h}$ & 3.50 & 171 & 28.08 & 6.09 \\
\hline & 42019 & 1 May 1990 & 31 December 2007 & $3 \mathrm{~h}$ & 3.00 & 132 & 17.33 & 7.62 \\
\hline & 42020 & 1 May 1990 & 31 December 2007 & $3 \mathrm{~h}$ & 3.00 & 92 & 17.33 & 5.31 \\
\hline & 42036 & 1 January 1994 & 31 December 2007 & $3 \mathrm{~h}$ & 3.00 & 81 & 13.67 & 5.93 \\
\hline & 42039 & 1 December 1995 & 31 December 2007 & $3 \mathrm{~h}$ & 3.00 & 95 & 12.00 & 7.92 \\
\hline & 42040 & 1 December 1995 & 31 December 2007 & $3 \mathrm{~h}$ & 3.00 & 80 & 12.00 & 6.67 \\
\hline
\end{tabular}

Results are shown in Tables 10 and 11 (respectively for the ECMWF and NOAA model data), which report the various parameters of the curves for all the buoy locations in the area.

Table 10. Gulf of Mexico: comparison between buoy (HD), ECMWF model (HM) and estimated $\left(\mathrm{H}_{\mathrm{S}}\right)$ significant wave height for various values of the return period $T_{R}$.

\begin{tabular}{cccccccccccccc}
\hline $\begin{array}{c}\mathbf{T}_{\mathbf{R}} \text { and Related } \\
\boldsymbol{\sigma} \text { Values }\end{array}$ & \multicolumn{3}{c}{$\mathbf{T}_{\mathbf{R}}=\mathbf{2 5}$ Years } & \multicolumn{3}{c}{$\mathbf{T}_{\mathbf{R}}=\mathbf{5 0}$ Years } & \multicolumn{3}{c}{$\mathbf{T}_{\mathbf{R}}=\mathbf{7 5}$ Years } & \multicolumn{3}{c}{$\mathbf{T}_{\mathbf{R}}=\mathbf{1 0 0}$ Years } \\
\cline { 2 - 14 } & \multicolumn{3}{c}{$\boldsymbol{\sigma}=\mathbf{0 . 1 7 2 2}$} & \multicolumn{3}{c}{$\boldsymbol{\sigma}=\mathbf{0 . 1 8 1 5}$} & \multicolumn{2}{c}{$\boldsymbol{\sigma}=\mathbf{0 . 1 8 6 2}$} & \multicolumn{2}{c}{$\boldsymbol{\sigma}=\mathbf{0 . 1 8 9 3}$} \\
\hline Location & HD & $\mathbf{H M}$ & $\mathbf{H}_{\mathbf{S}}$ & $\mathbf{H D}$ & $\mathbf{H M}$ & $\mathbf{H}_{\mathbf{S}}$ & $\mathbf{H D}$ & $\mathbf{H M}$ & $\mathbf{H}_{\mathbf{S}}$ & $\mathbf{H D}$ & $\mathbf{H M}$ & $\mathbf{H}_{\mathbf{S}}$ \\
\hline 42001 & 10.5 & 7.1 & 10.7 & 11.8 & 7.8 & 11.9 & 12.6 & 8.2 & 12.6 & 13.1 & 8.5 & 13.1 \\
42003 & 10.9 & 7.6 & 11.5 & 12.3 & 8.5 & 12.9 & 13.1 & 9.0 & 13.8 & 13.7 & 9.4 & 14.4 \\
42019 & 6.9 & 4.8 & 7.2 & 7.5 & 5.1 & 7.8 & 7.8 & 5.4 & 8.2 & 8.0 & 5.5 & 8.5 \\
42020 & 8.0 & 5.2 & 7.8 & 8.8 & 5.5 & 8.4 & 9.2 & 5.8 & 8.9 & 9.6 & 6.0 & 9.2 \\
42036 & 9.2 & 7.3 & 11.1 & 10.1 & 8.1 & 12.4 & 10.7 & 8.6 & 13.2 & 11.2 & 9.0 & 13.8 \\
42039 & 12.3 & 8.0 & 12.1 & 13.9 & 9.1 & 13.8 & 14.8 & 9.7 & 14.8 & 15.5 & 10.1 & 15.6 \\
42040 & 16.9 & 9.0 & 13.6 & 19.5 & 10.3 & 15.7 & 21.2 & 11.1 & 17.0 & 22.4 & 11.6 & 17.9 \\
\hline
\end{tabular}

Table 11. Gulf of Mexico: comparison between buoy (HD), NOAA model (HM) and estimated $\left(\mathrm{H}_{\mathrm{S}}\right)$ significant wave height for various values of the return period $T_{R}$.

\begin{tabular}{cccccccccccccc}
\hline $\begin{array}{c}\mathbf{T}_{\mathbf{R}} \text { and Related } \\
\boldsymbol{\sigma} \text { Values }\end{array}$ & \multicolumn{3}{c}{$\mathbf{T}_{\mathbf{R}}=\mathbf{2 5}$ Years } & \multicolumn{3}{c}{$\mathbf{T}_{\mathbf{R}}=\mathbf{5 0}$ Years } & \multicolumn{3}{c}{$\mathbf{T}_{\mathbf{R}}=\mathbf{7 5}$ Years } & \multicolumn{3}{c}{$\mathbf{T}_{\mathbf{R}}=\mathbf{1 0 0}$ Years } \\
\cline { 2 - 15 } & \multicolumn{3}{c}{$\boldsymbol{\sigma}=\mathbf{0 . 1 0 7 1}$} & \multicolumn{3}{c}{$\boldsymbol{\sigma}=\mathbf{0 . 1 1 4 5}$} & \multicolumn{3}{c}{$\boldsymbol{\sigma}=\mathbf{0 . 1 1 8 4}$} & \multicolumn{2}{c}{$\boldsymbol{\sigma}=\mathbf{0 . 1 2 1 0}$} \\
\hline Location & HD & $\mathbf{H M}$ & $\mathbf{H}_{\mathbf{S}}$ & $\mathbf{H D}$ & $\mathbf{H M}$ & $\mathbf{H}_{\mathbf{S}}$ & $\mathbf{H D}$ & $\mathbf{H M}$ & $\mathbf{H}_{\mathbf{S}}$ & $\mathbf{H D}$ & $\mathbf{H M}$ & $\mathbf{H}_{\mathbf{S}}$ \\
\hline 42001 & 10.5 & 8.3 & 10.6 & 11.8 & 9.2 & 11.7 & 12.6 & 9.7 & 12.4 & 13.1 & 10.0 & 12.9 \\
42003 & 10.9 & 9.1 & 11.5 & 12.3 & 10.1 & 12.9 & 13.1 & 10.7 & 13.8 & 13.7 & 11.2 & 14.4 \\
42019 & 6.9 & 5.5 & 7.0 & 7.5 & 5.9 & 7.6 & 7.8 & 6.2 & 7.9 & 8.0 & 6.4 & 8.2 \\
42020 & 8.0 & 5.9 & 7.5 & 8.8 & 6.5 & 8.3 & 9.2 & 6.8 & 8.7 & 9.6 & 7.0 & 9.1 \\
42036 & 9.2 & 8.3 & 10.6 & 10.1 & 9.3 & 11.9 & 10.7 & 9.8 & 12.7 & 11.2 & 10.3 & 13.2 \\
42039 & 12.3 & 9.8 & 12.5 & 13.9 & 11.1 & 14.2 & 14.8 & 11.8 & 15.2 & 15.5 & 12.3 & 15.9 \\
42040 & 16.9 & 11.5 & 14.6 & 19.5 & 13.1 & 16.7 & 21.2 & 14.0 & 18.1 & 22.4 & 14.7 & 19.0 \\
\hline
\end{tabular}




\section{Discussion}

The first-if perhaps expected-result of the work is that the difference between the model derived curve $\mathrm{HM}\left(\mathrm{T}_{\mathrm{R}}\right)$ and the experimental curve is always negative, i.e., the model results present a consistent negative bias in the estimation of extreme events. There are of course various reasons why this is the case-in the first place the already mentioned limitations due to the model's inherent limits [38-40]; a further practical reason is the effect, also discussed above, caused by the longer sampling time of the model data in comparison with the high data sampling of modern wave buoys $\left(30^{\prime}\right)$, which also coincide with the standard engineering practice.

Once the bias curve for a given area is computed, $\mathrm{H}_{S}\left(\mathrm{~T}_{\mathrm{R}}\right)$ can easily be obtained by adding the bias to the model values $\mathrm{HM}\left(\mathrm{T}_{\mathrm{R}}\right) . \mathrm{H}_{S}\left(\mathrm{~T}_{\mathrm{R}}\right)$ always presents a marked improvement in comparison with the simple model data $\operatorname{HM}\left(T_{R}\right)$, so it always make sense to correct model derived data with an estimate of the error distribution in the local buoy wave meters.

Another important aspect is the information gained on the uncertainty of the model-derived extreme value curves by considering the variation of statistical parameters over a given area (spatial analysis). Confidence intervals have been provided for $68 \%( \pm 1 \sigma)$ and $95 \%( \pm 2 \sigma)$, and it was found that most of the $\operatorname{HD}\left(T_{R}\right)$ curves derived from real data at the buoy locations fall well within the $\pm 1 \sigma$ interval of the estimated $\mathrm{H}_{S}\left(\mathrm{~T}_{R}\right)$, all of them however being actually within the $\pm 2 \sigma$ curves. Given the relatively small number of buoys in each sea region, this behavior it is coherent with what could have been expected. More importantly, perhaps, $\mathrm{H}_{S}\left(\mathrm{~T}_{\mathrm{R}}\right)$ always showed a marked improvement in comparison with the simple model data $\operatorname{HM}\left(\mathrm{T}_{R}\right)$. This also holds for the particular case of the Southern Italian buoys, which are all located in the same area, but face different directions due to the complex coast morphology. The fact that the results are not much different from those in the other directions, seems to confirm that the wave models are accurate enough to take the wave generation into account, and that most of the uncertainty derives from the wind modelling part of the chain.

\section{Conclusions}

The paper shows that a probabilistic estimate $\mathrm{H}_{S}\left(\mathrm{~T}_{R}\right)$ of the significant wave height $\mathrm{H}_{S}$ as a function of the return time $T_{R}$ is possible by comparing wave buoy (direct) and model (indirect) data in a given area. $H_{S}\left(T_{R}\right)$ functions obtained from historical buoy data have been compared with similar curves derived from indirect data from both ECMWF and NOAA archives for three distinct areas: the Gulf of Mexico, the North Atlantic waters along the Spanish coasts and part of the Mediterranean Sea surrounding Italy. The comparison shows a systematic negative bias, thus proving that model curves always underrate experimental ones. The error distribution of the model of the data was studied on a geographical basis, so that a $\mathrm{H}_{S}\left(\mathrm{~T}_{\mathrm{R}}\right)$ curve and its confidence values can be evaluated for any model grid point in the area. Widely diffused, freely available and reliable model data archives such as ECMWF and NOAA analysis and reanalysis data can thus be used for engineering purposes.

While the objective of the work is not to suggest a particular extreme value distribution or estimation methodology, a general procedure has been provided to improve the reliability of model data for EVA; such a procedure, already in the present form, can also be used to evaluate the suitability of a given model data archive to the estimation of the probability of extreme sea states.

Further development should include testing the procedure with some of the new commercially available model data sets which present a higher spatial and temporal resolution. This would allow an independent assessment of their quality as well as-possibly-a better estimate of the extreme value $\mathrm{SWH}$.

Acknowledgments: Most of the work described in the paper was carried out within CUGRI (University Joint Research Centre on Major Hazards). The authors are grateful to Giovanni Besio (University of Genoa), Gabriele Nardone (APAT-ISPRA, Italian Environmental Agency), and Lucio Torrisi (CNMCA-Italian Air Force Meteorological Office), for useful data and helpful discussions. Model data from ECMWF (European Centre for Medium-Range Weather Forecast) and from NOAA NCEP. Wave buoys data from ISPRA (Italian coasts), Puertos de l'Estado (Spanish North Atlantic) and from NOAA-National Data Buoy Center (Mexican Gulf). 
Author Contributions: F.D. and F.R. carried out the elaborations on the wave data and developed the maritime engineering part; P.F. developed the statistical parts; P.C. revised the text and developed the marine engineering part; E.P.C. and G.R.T. supervised the work.

Conflicts of Interest: The authors declare no conflict of interest.

\section{References}

1. Salvadori, G.; Tomasicchio, G.R.; D'Alessandro, F. Multivariate approach to design coastal and off-shore structures. J. Coast. Res. 2013, 1, 386-391. [CrossRef]

2. Salvadori, G.; Tomasicchio, G.R.; D'Alessandro, F. Practical guidelines for multivariate analysis and design in coastal adn off-shore engineering. Coast. Eng. 2014, 88, 1-14. [CrossRef]

3. Cavaleri, L.; Sclavo, M. The calibration of wind and wave model data in the Mediterranean Sea. Coast. Eng. 2006, 53, 613-627. [CrossRef]

4. Longuet-Higgins, M.S.; Cartwright, D.E.; Smith, N.D. Observations of the directional spectrum of sea waves using the motion of a floating buoy. In Ocean Wave Spectra, 1st ed.; Prentice-Hall: Englewood Cliffs, NJ, USA, 1963; pp. 111-132.

5. Kuik, A.J.; Ph van Vledder, G.; Holthuijsen, L.H. A Method for the Routine Analysis of Pitch-and-Roll Buoy Wave Data. J. Phys. Oceanogr. 1988, 18, 1020-1034. [CrossRef]

6. Bencivenga, M.; Nardone, G.; Ruggiero, F.; Calore, D. The Italian Data Buoy Network. WTI Trans. Eng. Sci. 2012, 74, 321-332. [CrossRef]

7. Vicinanza, D.; Contestabile, P.; Ferrante, V. Wave energy potential in the north-west of Sardinia (Italy). Renew. Energy 2013, 50, 506-521. [CrossRef]

8. Iuppa, C.; Cavallaro, L.; Vicinanza, D.; Foti, E. Investigation of suitable sites for wave energy converters around Sicily (Italy). Ocean Sci. 2015, 11, 543-557. [CrossRef]

9. Iuppa, C.; Cavallaro, L.; Foti, E.; Vicinanza, D. Potential wave energy production by different wave energy converters around Sicily. J. Renew. Sust. Energy 2015, 7. [CrossRef]

10. Arena, F.; Laface, V.; Barbaro, G.; Romolo, A. Effects of Sampling between Data of Significant Wave Height for Intensity and Duration of Severe Sea Storms. Intern J. Geosci. 2013, 4, 240-248. [CrossRef]

11. Reale, F.; Dentale, F.; Pugliese Carratelli, E.; Torrisi, L. Remote Sensing of Small-Scale Storm Variations in Coastal Seas. J. Coast. Res. 2014, 30, 130-141. [CrossRef]

12. Mentaschi, L.; Besio, G.; Cassola, F.; Mazzino, A. Performance evaluation of Wavewatch III in the Mediterranean Sea. Ocean Model. 2015, 90, 82-94. [CrossRef]

13. Cavaleri, L.; Bertotti, L. The improvement of modelled wind and wave fields with increasing resolution. Ocean Eng. 2006, 33, 553-565. [CrossRef]

14. Bertotti, L.; Cavaleri, L.; Soret, A.; Tolosana-Delgado, R. Performance of global and regional nested meteorological models. Cont. Shelf Res. 2014, 87, 17-27. [CrossRef]

15. Abdalla, S.; Cavaleri, L. Effect of wind variability and variable air density on wave modelling. J. Geophys. Res. 2002, 107(C7). [CrossRef]

16. Dentale, F.; Reale, F.; D’Alessandro, F.; Damiani, L.; Di Leo, A.; Pugliese Carratelli, E.; Tomasicchio, G.R. Sampling Bias in the Estimation of Significant Wave Height Extreme Values. In Proceedings of the 35th Conference on Coastal Engineering, Antalya, Turkey, 17-20 November 2016.

17. Benetazzo, A.; Barbariol, F.; Bergamasco, F.; Carniel, S.; Sclavo, M. Space-time extreme wind waves: Analysis and prediction of shape and height. Ocean Model. 2017, 113, 201-216. [CrossRef]

18. Komen, G.J.; Cavaleri, L.; Donelan, M.; Hasselmann, K.; Hasselmann, S.; Janssen, P.A.E.M. Dynamics and Modelling of Ocean Waves, 1st ed.; Cambridge University Press: Cambridge, UK, 1994; p. 532.

19. Chua, S.-H.; Bras, L.R. Estimation of Stationary and Non-stationary Random Fields: Kriging in the Analysis of Orographic Precipitation, 1st ed.; Massachusetts Institute of Technology, Department of Civil Engineering, Ralph M. Parsons Laboratory for Water Resources and Hydrodynamics: Cambridge, MA, USA, 1980; p. 171.

20. Slimani, M.; Obled, C. Regionalization of extreme rainfall parameters through kriging and correlation with topography descriptors. In Regional Flood Frequency Analysis, Proceedings of the International Symposium on Flood Frequency and Risk Analysis, Louisiana State University, Baton Rouge, LA, USA, 14-17 May 1986.

21. Prudhomme, C.; Reed, D.W. Mapping extreme rainfall in a mountainous region using geostatistical techniques: A case study in Scotland. Int. J. Climatol. 1999, 90, 1337-1356. [CrossRef] 
22. Pelosi, A.; Furcolo, P. An Amplification Model for the Regional Estimation of Extreme Rainfall within Orographic Areas in Campania Region (Italy). Water 2015, 7, 6877-6891. [CrossRef]

23. Seo, D.-J.; Breidenbach, J.P.; Johnson, E.R. Real-time estimation of mean field bias in radar rainfall data. J. Hydrol. 1999, 223, 131-147. [CrossRef]

24. Harrison, D.L.; Scovell, R.W.; Kitchen, M. High-resolution precipitation estimates for hydrological uses. Proc. Inst. Civ. Eng. Water Manag. 2009, 162, 125-135. [CrossRef]

25. Krajewski, W.F. Cokriging radar-rainfall and rain gage data. J. Geophys. Res. Atmos. 1987, 92, 9571-9580. [CrossRef]

26. Todini, E. A Bayesian technique for conditioning radar precipitation estimates to rain-gauge measurements. Hydrol. Earth Syst. Sci. 2001, 5, 187-199. [CrossRef]

27. Chumchean, S.; Sharma, A.; Seed, A. An Integrated Approach to Error Correction for Real-Time Radar-Rainfall Estimation. J. Atmos. Ocean. Tech. 2006, 23, 67-79. [CrossRef]

28. Goda, Y. Statistical Analysis of Extreme Waves. In Random Seas and Design of Maritime Structures, 1st ed.; Liu, P.L.-F., Ed.; World Scientific Publishing Co. Pte. Ltd.: Singapore, 2000; Volume 15, pp. 377-425, ISBN 981-02-3256-X.

29. Thompson, P.; Cai, Y.; Reeve, D.; Stander, J. Automated threshold selection methods for extreme wave analysis. Coast. Eng. 2009, 56, 1013-1021. [CrossRef]

30. Feng, X.; Tsimplis, M.N.; Quartly, G.D.; Yelland, M.J. Wave height analysis from 10 years of observations in the Norwegian Sea. Cont. Shelf Res. 2014, 72, 47-56. [CrossRef]

31. Sartini, L.; Mentaschi, L.; Besio, G. Comparing different extreme wave analysis models for wave climate assessment along the Italian coast. Coast. Eng. 2015, 100, 37-47. [CrossRef]

32. Sartini, L.; Cassola, F.; Besio, G. Extreme waves seasonality analysis: An application in the Mediterranean Sea. J. Geophys. Res. Oceans 2015, 120, 6266-6288. [CrossRef]

33. Sartini, L.; Besio, G.; Dentale, F.; Reale, F. Wave Hindcast Resolution Reliability for Extreme Analysis. In Proceedings of the 26th International Ocean and Polar Engineering, Rhodes, Greece, 26 June-2 July 2016; International Society of Offshore and Polar Engineers (ISOPE): Cupertino, CA, USA, 2016.

34. Leadbetter, M.R. On a basis for 'Peaks over Threshold' modelling. Stat. Probabil. Lett. 1991, 12, $357-362$. [CrossRef]

35. Abild, J.; Andersen, E.Y.; Rosbjerg, D. The climate of extreme winds at the great belt, Denmark. J. Wind Eng. Ind. Aerod. 1992, 41, 521-532. [CrossRef]

36. Mathiesen, M.; Goda, Y.; Hawkes, P.J.; Mansard, E.; Martín, M.J.; Peltier, E.; Thompson, E.F.; Van Vledder, G. Recommended practice for extreme wave analysis. J. Hydraul. Res. 1994, 32, 803-814. [CrossRef]

37. Anderson, E. User Guide to ECMWF Forecast Products. Available online: https:/ / www.ecmwf.int/sites / default/files/User_Guide_V1.2_20151123.pdf (accessed on 28 February 2018).

38. Moeini, M.H.; Etemad-Shahidi, A.; Chegini, V.; Rahmani, I.; Moghaddam, M. Error distribution and correction of the predicted wave characteristics over the Persian Gulf. Ocean Eng. 2014, 75, 81-89. [CrossRef]

39. Sulis, A.; Cozza, R.; Annis, A. Extreme wave analysis methods in the gulf of Cagliari (South Sardinia, Italy). Ocean Coast. Manag. 2017, 140, 79-87. [CrossRef]

40. Contestabile, P.; Di Lauro, E.; Buccino, M.; Vicinanza, D. Economic Assessment of Overtopping BReakwater for Energy Conversion (OBREC): A Case Study in Western Australia. Sustainability 2017, 9, 51. [CrossRef]

(C) 2018 by the authors. Licensee MDPI, Basel, Switzerland. This article is an open access article distributed under the terms and conditions of the Creative Commons Attribution (CC BY) license (http:/ / creativecommons.org/licenses/by/4.0/). 